Volume 10 Nomor 2 https $: / /$ jurnal.syedzasaintika.ac.id

\title{
Pengaruh Perasan Air Daun Cincau Hijau (Cyclea Berbata Miers) Terhadap Tekanan Darah Pada Penderita Hipertensi Di Wilayah Kerja Puskesmas Andalas
}

\section{The Influence of Cyclea Berbata Miers Water Pressure on Blood Pressure in Hypertension Patients in Andalas Health Center}

\author{
Ibrahim, Eliza Arman, Widia Permata Putri \\ STIKES Syedza Saintika \\ (anggabhaim@gmail.com)
}

\begin{abstract}
ABSTRAK
Menurut data World health organization di seluruh dunia sekitar 972 juta orang diseluruh dunia menderita hipertensi. Salah satu obat nonfarmakologi untuk penderita hipertensi adalah cylea berbata miers.Penelitian ini bertujuan untuk mengetahui pengaruh pemberian perasan air daun cincau hijau terhadap tekanan darah pada penderita hipertensi di wilayah kerja puskesmas Andalas.Jenis penelitianquasi-eksperimen design dengan pendekatan Pretest posttest one group design. Penelitian ini dilaksanakan di Wilayah Kerja Puskesmas Andalas Tanggal 29 Agustus sampai 4 September Tahun 2018. Populasi penelitian ini sebanyak 302 orang. Teknik sampel adalah Purposive Sampling sebanyak 16 orang. Data dianalis is menggunakanan univariat dan bivariat dengan menggunakan Uji Paired Sampel Test. Tekanan darah sebelum diberikan perasan air daun cincau hijausistolik 156,25 mmHg dan diastolik 95,38 $\mathrm{mmHg}$ dan sesudah diberikan perasan air daun cincau hijausistolik $150,75 \mathrm{mmHg}$ dan diastolik 91,62 $\mathrm{mmHg}$. Hasil uji statistikdidapatkan nilai $\mathrm{p}=0,000$ berarti pada $\alpha=0,05$. Hasil penelitian ini dapat di simpulkan bahwa terlihat ada pengaruh pemberian perasan air daun cincau hijau terhadap penurunan tekanan darah sistolik dan diastolik pada penderita hipertensi. Petugas kesehatan agar memberikan pendidikan kesehatan tentang pemanfaatan tanaman obat tradisional khususnya pengunaan perasan air daun cincau hijau untuk masyarakat dan keluarga dalam langkah pertama pencegahan penyakit hipertensi.
\end{abstract}

\section{Kata Kunci : Daun Cincau Hijau, Hipertensi}

\section{ABSTRACT}

According to data from the World Health Organization around the world around 972 million people worldwide suffer from hypertension. One of the non-pharmacological drugs for hypertension sufferers is cylea with miers. This study aims to determine the effect of the administration of green grass jelly juice to blood pressure in patients with hypertension in the working area of Andalas Community Health Center. This type of research is quasi-experimental design with a pretest posttest one group design approach. This research was conducted in the working area of Andalas Community Health Center on 29 August to 4 September 2018. The population of the study was 302 people. The sampling technique was purposive sampling of 16 people. Data were analyzed using univariate and bivariate using the Paired Sample Test. Blood pressure before being given juice of systolic green grass jelly leaves $156.25 \mathrm{mmHg}$ and diastolic $95.38 \mathrm{mmHg}$ and after being given juice of systolic green grass jelly leaves $150.75 \mathrm{mmHg}$ and diastolic 


\title{
Jurnal Kesehatan Medika Saintika
}

\author{
Volume 10 Nomor 2 https $: / /$ jurnal.syedzasaintika.ac.id
}

91.62 $\mathrm{mmHg}$. Statistical test results obtained $p=0,000$ means that at $\alpha=0.05$. The results of this study can be concluded that there was an effect of the administration of green grass jelly juice to a decrease in systolic and diastolic blood pressure in patients with hypertension. Health workers should provide health education about the use of traditional medicinal plants, especially the use of green grass jelly juice for the community and family in the first step in preventing hypertension.

Keywords: Cyclea Berbata Miers, Hypertension

\section{PENDAHULUAN}

Hipertensi juga sering disebut sebagai silent killer karena termasuk penyakit yang mematikan. Bahkan, hipertensi tidak dapat secara langsung membunuh penderitanya, melainkan hipertensi memicu terjadinya penyakit lain yang tergolong kelas berat dan mematikan serta dapat meningkatkan resiko serangan jantung, gagal jantung, stroke, dan gagal ginjal (Pudiastuti, 2013).

Menurut data World health organization (2016)di seluruh dunia sekitar 972 juta orang atau $26,4 \%$ orang diseluruh dunia mengidap hipertensi, angka ini memungkinkan akan meningkat menjadi 29,2\% ditahun 2025. Dari 972 juta pengidap hipertensi, 333 juta berada di Negara maju dan 639 sisanya berada di Negara berkembang, termasuk Indonesia. Penyakit terbanyak pada usia lanjut berdasarkan Riset Kesehatan Dasar tahun 2013 adalah hipertensi. Dengan prevalensi 45,9\% pada usia 55-64 tahun, 57,6\% pada usia $65,74 \%$ dan $63,8 \%$ pada usia $\geq 75$ tahun.Data dari Dinas Kesehatan Kota Padang (2016) menunjukkan hipertensi merupakanpenyakit terbanyak yang diderita oleh masyarakat, angka kejadian hipertensi ini dilihat dari 22 puskesmas yang ada di kota Padang penderitanya sebanyak 1029 orang. Jumlah penderita hipertensi di Puskesmas Andalas252 orang pada tahun 2017.

Hipertensi biasanya bersifat asimptomatik, tetapi memiliki angka mordilitas dan mortalitas yang relative tinggi. Tekanan darah makin tinggi, makin beresiko terkena Coronary Disease, Congestive Heart Failure (CHF), stroke dan kidney disease. Hipertensi juga dapat menimbulkan berbagai macam komplikasi yang dapat mengenai suatu target organ, misalnya stroke dan penyakit jantung coroner (Borzecki, Kader, \& Berlowitz, 2010).Kematian akibat kardiovaskuler secara global adalah sekitar 17 juta kematian per tahun disebabkan oleh komplikasi akibat hipertensi. Hipertensi bertanggung jawab untuk setidaknya 45\% kematian akibat penyakit jantung dan $51 \%$ akibat stroke.

Penanganan hipertensi dibagi dua bagian yakni secara farmakologis dan non farmakologis. Penanganan secara farmakologis dengan mengunakan obatobat seperti diuritik, simpatik, betablocker, dan vasodilator yang dapat membantu menurunkan dan menstabilkan tekanan darah, serta menurunkan risiko terjadinya komplikasi akibat hipertensi (Davey, 2005).

Penanganan secara non farmakologis yaitu mengurangi berat badan untuk individu yang obesitas atau gemuk, mengadopsi pola makan DASH (Dietary Approach to Stop Hypertension) yang kaya akan kalium dan kalsium, aktifitas fisik, dan terapi komplementer (Klodas, 2012). Pengobatan alternatif menjadi pilihan untuk mengatasi hipetensi, salah satunya dengan terapi herbal dan manfaat yang tidak kalah dengan obat kimia bahkan dengan keuntungannya yang tidak memiliki efek samping bagi penderita 


\title{
Jurnal Kesehatan Medika Saintika
}

\author{
Volume 10 Nomor 2 https $: / /$ jurnal.syedzasaintika.ac.id
}

(Nurrahmani, 2012). Salah satu terapi herbal untuk mengobati penyakit hipertensi adalah dengan mengkonsumsi perasan air daun cincau hijau karena tanaman daun cincau hijau kaya akan zat aktif flavonoid dan alka loid (Katrin et al, 2012).

Tanaman cincau termasuk tanaman asli Indonesia.Ada empat jenis cincau yang dikenal oleh masyarakat yaitu cincau hijau, cincau hitam, cincau minyak dan cincau perdu.Umumnya dari dari keempat jenis tanaman cincau tersebut yang paling digemari oleh masyarakat adalah cincau hijau. Olahan daun cincau hijau biasanya dihidangkan bersama minuman segar atau bisa juga diolah menjadi pudding dan agar-agar (Afifah, 2015).

Menurut Sabilla (2016), cincau sudah dikenal oleh masyarakat sebagai pangan penurunan panas (demam), mual, obat radang lambung,batuk dan penurunan tekanan darah tinggi. Daun Cyclea barbata Miers diketahui mengandung klorofil, serta senyawa bioaktif flavonoiddapat memberikan efek vasodilatasi terhadap pembuluh darah yang membantu melindungi fungsi jantung dan flavonoid juga dapat menurunkan kekuatan arteri.

Menurut Djam'an (2008), daun cincau hijau mengandung karbohidrat, lemak protein, klorofil dan senyawasenyawa lainnya seperti polifenol, flavonoid, serta mineral dan vitamin diantaranya kalsium, fosfor, Vitamin A, dan vitamin B. Kandungan polifenol dan flavonoid yang terkandung dari daun cincau hijau dapat berfungsi sebagai antioksidan. Senyawa bioaktiftersebut memiliki peran penting dalam mekanisme antihipertensi.Cara kerja senyawa tersebut langsung menuju kepusat jaringan, seperti jantung, vascular, dan system syaraf. Kenaikan tekanan darah akan menyebabkan vasokontriksi pada pembuluh darah.
Senyawa flavonoid dan alkaloid langsung bekerja pada system syaraf melalui mekanisme simpatolitik dan atau parasimpatomimetik, yaitu relaksasi otot atau melalui syaraf pusat. Kerja simpatolitik yaitu dengan cara menurunkan tekanan darah melalui penurunan curah jantung melalui hambatan reseptor $\beta 1$, mendilatasi pembuluh darah melalui hambatah reseptor $\alpha 1$ atau $\beta 2$. Bisa juga dengan cara menghambat pelepasan neurotransmitter andregenik.

Penelitian yang dilakukan oleh Karina et al (2014) menunjukkan pemberian air perasan caincau hijau dapat menurunkan tekanan darah 15-30 mmHg, sedangkan Iswan (2014), menunjukkan bahwa daun cincau hijau dapat menurunkan tekanan darah 5,8 mmHg hal ini dikarenakan air perasan daun cincau hijau mengandung flavonoid dan alkaloid yang tinggi, kandungan zat aktif flavonoid dapat memberikan efek vasodilatasiterhadap pembuluh darah yang membantu melindungi fungsi jantung. Menurut Guyton (2008), flavonoid dapat mengurangi sekresi rennin yang menyebabkan penurunan angiotensin II sehingga vasokontriksi pembuluh darah berkurang dan menurunnya aldosentron sehingga reabsobsi natrium dan air berkurang.

Berdasarkan survey awal yang peneliti lakukan pada tanggal 17April 2018 dengan mewawancarai 10 orang pasien Hipertensi yang berkunjung ke Wilayah Kerja Puskesmas Andalas diketahui bahwa 6 orang pasien hipertensi tidak mengetahui manfaat dan kegunaan dari perasan air daun cincau hijau untuk penurunan tekanan darah yang mereka tahu jika tekanan darah naik, mereka minum obat saja dan 4 orang mengatakan mengetahui tentang air rebusan daun cincau hijau tetapi karena malas mencarinyamaka mereka 


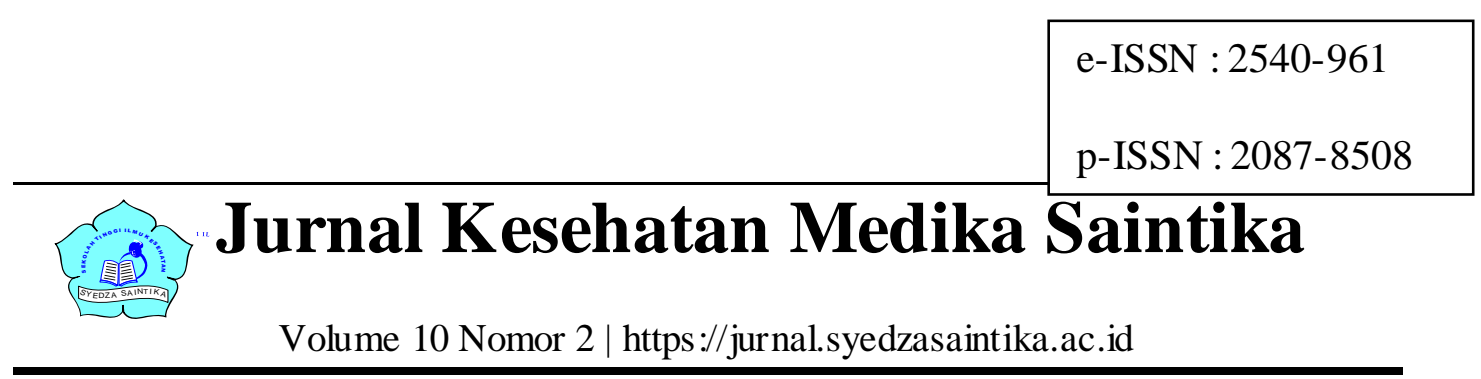

tidak meminumnya sebagai penurunan tekanan darah.

Berdasarkan masalah diatas maka peneliti telah melakukan penelitian tentang pengaruh perasan air daun cincau hijau (cyclea berbata miers) terhadap tekanan darah pada penderita hipertensi.

\section{METODE PENELITIAN}

Penilitian dilakukan di wilayah kerja Puskesmas Andalas. Penelitian ini merupakan penilitian kuantitatif dengan desain penilitian quasi eksperiment designyaitu pre test-post test bertujuan untuk mengetahui perubahan tekanan darah sistolik dan tekanan darah diastolik sebelum dan sesudah pemberian perasan air daun cincau hijau. Populasi penelitian ini adalah semua pasien yang menderita penyakit hipertensi di wilayah kerja Puskesmas Andalasdenganjumlah sampel yang diambil peneliti sebanyak 16 orang. Penelitian ini dilaksanakan di Wilayah Kerja Puskesmas Andalas, dengan waktu pelaksanaan penelitian selama 7 hari, dengan cara mengukur takanan darah sebelum pemberian perasan air daun cincau hijau dan sesudah pemberian perasan air daun cincau hijau.Teknik pengambilan sampel mengunakan teknik purposive sampling.Data diolah secara komputerisasi yang dimulai dari editing, coding, entry, cleaning. Analisis data dilakukan secara univariat dan bivariat dengan menggunakan uji statistic uji $T$ test-dependen.

\section{HASIL PENELITIAN}

1. Analis is Univariat

a. Rata-Rata Tekanan Darah pada Penderita Hipertensi Sebelum diberikan Perasan AirDaun Cincau Hijau (Cyclea Barbata Miers)
Berdasarkan hasil penelitian, didapatkan rata-rata tekanan darah penderita hipertensi sebelum diberikan perasan air daun cincau hijau (Cyclea Barbata Miers)yaitu $156,25 / 95,38 \mathrm{mmHg}$ dengan selisih $\quad 60,87 \mathrm{mmHg}$ dengan standar deviasi yaitu $3,000 / 2,500$ $\mathrm{mmHg}$. Tekanan darah terendah adalah 152/90 mmHg dan Tekanan Darah tertinggi adalah 160/98 mmHgdi wilayah kerja Puskesmas Andalas.

b. Rata-Rata Tekanan Darah pada Penderita Hipertensi Sesudah diberikan Perasan Air Daun Cincau Hijau

Berdasarkan hasil penelitian, didapatkan rata-rata tekanan darah penderita hipertensi sesudah diberikan perasan air daun cincau hijau yaitu 150,75/91,62 $\mathrm{mmHg}$ dengan standar deviasi yaitu 2,817/1,821 mmHg. Tekanan darah terendah adalah 146/88 $\mathrm{mmHg}$ dan tertinggi adalah 156/94 mmHgdi Wilayah Kerja Puskesmas Andalas Padang.

\section{Analisis Bivariat}

a. Pengaruh Pemberian Perasan air daun cincau hijauTerhadap Tekanan Darah pada Penderita Hipe rtensi

Berdasarkan hasil penelitian, didapatkan selisih rata-rata tekanan darah sebelum dan sesudah diberikan perasan air daun cincau hijau (Cyclea Barbata Miers) yaitu 5,500/8,50 mmHg. Hasil uji statistik t-test dependendan

Willxocondidapatkan nilai $\mathrm{p}=$ 0,000 berarti pada $\alpha<0,05$ terlihat ada pengaruh pemberian perasan air daun cincau hijau terhadap penurunan tekanan darah sistolik dan diastolik pada penderita 


\title{
Jurnal Kesehatan Medika Saintika
}

\author{
Volume 10 Nomor 2 |https $/ /$ jurnal.syedzasaintika.ac.id
}

hipertensi di Wilayah Kerja Puskesmas Andalas.

\section{PEMBAHASAN}

1. Analis is Univariat

Rata-Rata Tekanan Darah pada Penderita Hipertensi Sebelum diberikan Perasan AirDaun Cincau Hijau (Cyclea Barbata Miers)

Berdasarkan hasil penelitian, didapatkan rata-rata tekanan darah penderita hipertensi sebelum diberikan perasan air daun cincau hijau (Cyclea Barbata Miers)yaitu 156,25/95,38 $\mathrm{mmHg}$ dengan selisih $60,87 \mathrm{mmHg}$ dengan standar deviasi yaitu 3,000/2,500 $\mathrm{mmHg}$. Tekanan darah terendah adalah 152/90 mmHg dan Tekanan Darah tertinggi adalah 160/98 mmHgdi wilayah kerja Puskesmas Andalas.

Hasil penelitian ini sejalan dengan penelitian yang dilakukan oleh Yandri Barma Putra,tentang pengaruh pemberian perasan air daun cincau hijau (Cyclea Barbata Miers) terhadap tekanan darah pada penderita hipertensi di Dusun DepokAmbarketawang Gamping Sleman Yogyakarta, ditemukan rata-rata tekanan darah systole sebelum di berikan perasan air daun cincau hijau adalah $155,71 \mathrm{mmHg}$ sedangkan rata-rata tekanan darah systole sesudah di berikan perasan air daun cincau hijau adalah 136,42 $\mathrm{mmHg}$. Selisih rata-rata tekanan darah systole sebelum dan sesudah di berikan perasan air daun cincau hijausebanyak 19,28 mmHg. Sedangkan tekanan darah diastole sebelum diberikan perasan air daun cincau hijau adalah 96,42 $\mathrm{mmHg}$ sedangkan rata-rata tekanan darah systole sesudah di berikan perasan air daun cincau hijau adalah 82,14 $\mathrm{mmHg}$. Selisih rata-rata sebelum dan sesudah pemberian perasan air daun cincau hijau sebanyak 14,28 mmHg(Yandri Barma Putra, 2017).
Hipertensi merupakan keadaan ketika tekanan darah sistolik lebih dari120 $\mathrm{mmHg}$ dan tekanan diastolik lebih dari $80 \mathrm{mmHg}$. Hipertensi sering menyebabkan perubahan pada pembuluh darah yang dapat mengakibatkan semakin tingginya tekanan darah. Hipertensi dapat terjadi pada siapa pun, baik lelaki maupun perempuan pada segala umur. Hampir 90\% kasus hipertensi tidak diketahui penyebab sebenarnya, bahkan pada sebagian besar kasus hipertensi tidak memberikan gejala (asistomatis). Meskipun secara tidak sengaja, beberapa gejala terjadi bersamaan dan dipercaya berhubungan dengan hipertensi padahal sesungguhnya bukan hipertensi. Gejala yg mungkin muncul nyeri kepela saat terjaga, kadang-kadang disertai mual dan muntah, akibat peningkatan tekanan darah intrakranial.Penglihatan kabur akibat kerusakan retina akibat hipertensi, Ayunan langkah yang tidak mantap karena kerusakan susunan saraf pusat, Edema dependen dan pembengkakan akibat peningkatan tekanan kapiler (Crowin, 2000).

Hipertensi biasanya bersifat asimptomatik, tetapi memiliki angka mordibitas dan mortalitas yang relative tinggi. Tekanan darah makin tinggi, makin beresiko terkena Coronary Disease, Congestive Heart Failure (CHF), stroke dan kidney disease. Hipertensi juga dapat menimbulkan berbagai macam komplikasi yang dapat mengenai suatu target organ, misalnya stroke dan penyakit jantung koroner (Borzecki, Kader \& Berlowitz, 2010).

Asumsi peneliti, sebelum diberikan perasan air daun cincau hijau (Cyclea Barbata Miers)rata-rata 156,25/95,38 $\mathrm{mmHg}$, hal ini dapat disebabkan karena kebiasaan penderita hipertensi seperti mengkonsumsi makanan yang mengandung garam $>90 \mathrm{mmol} / \mathrm{hari}$. Dan juga disebabkan oleh banyak pikiran 


\section{Jurnal Kesehatan Medika Saintika}

Volume 10 Nomor 2 https $\% /$ jurnal.syedzasaintika.ac.id

dimana semakin banyakyg di pikirkan, maka dapat menaikan tekanan darah. Hipertensi juga dapat terjadi akibat pola makan dan gaya hidup yang tidak sehat, seperti, asupan tinggi lemak dan penguat rasa makanan, stress, dan merokok. Disamping itu responden belum pernah menggunakan perasan air daun cincau hijau untuk mengatasi hipertensi kecuali hanya untuk minuman pelepas dahaga saja. Padahal daun cincau hijau tergolong relative terjangkau dan mudah didapat.

\section{Rata-Rata Tekanan Darah pada Penderita Hipertensi Sesudah diberikan Perasan Air Daun Cincau Hijau}

Berdasarkan hasil penelitian, didapatkan rata-rata tekanan darah penderita hipertensi sesudah diberikan perasan air daun cincau hijau yaitu $150,75 / 91,62 \mathrm{mmHg}$ dengan standar deviasi yaitu $2,817 / 1,821 \mathrm{mmHg}$. Tekanan darah terendah adalah 146/88 $\mathrm{mmHg}$ dan tertinggi adalah 156/94 mmHgdi Wilayah Kerja Puskesmas Andalas Padang Tahun 2018.

Hasil penelitian ini sama dengan penelitian yang dilakukan oleh Istiroha (2016) tentang pengaruh perasan air daun cincau hijau terhadap penurunan tekanan darah pada penderita hipertensi di Desa Setrohadi Kecamatan Duduk Sampeyan Gresik. Ditemukan rata-rata setelah diberikan perasan air daun cincau hijau tekanan darah turun dengansistole 10-30 $\mathrm{mmHg}$ dan diastolik 5-25 mmHg.

Penanganan hipertensi dibagi dua bagian yakni secara farmakologis dan non farmakologis. Penanganan secara farmakologis dengan menggunakan obat-obatan seperti diuretik, simpatik, betabloker, dan vasodilator yang dapat membantu menurunkan dan menstabilkan tekanan darah, serta menurunkan risiko terjadinya komplikasi akibat hipertensi (Davey, 2005).

Penanganan secara non farmakologis yaitu mengurangi berat badan untuk individu yang obesitas atau gemuk, mengadopsi pola makan DASH (Dietary Approach to Stop Hypertension) yang kaya akan kalium dan kalsium, aktifitas fisik dan terapi herbal (Klodas, 2012). Pengobatan alternatif menjadi pilihan untuk mengatasi hipertensi, salah satunya dengan terapi herbal dengan manfaat yang tidak kalah dengan obat kimia bahkan dengan keuntungannya yang tidak memiliki efek samping bagi penderita (Nurrahmani, 2012).Salah satu terapi herbal untuk mengobati penyakit hipertensi adalah dengan mengkonsumsi perasan air daun cincau hijau karena tanaman daun cincau hijau kaya akan zat aktif flavonoid dan alkaloid (Katrin et al, 2012).

Asumsi peneliti, sesudah diberikan perasan air daun cincau hijau terdapat penurunan tekanan darah penderita hipertensi hari ke 3 hal ini karena pemberian perasan air daun cincau hijau yang diberikan setiap hari 1 kali sehari pada siang harisebanyak $200 \mathrm{ml}$ diberikan selama 7 hari dapat memberikan efek menurunkan tekanan darah, dimana perasan air daun cincau hijau diketahui mengandung klorofil, serta senyawa bioaktif flavonoiddapat memberikan efek vasodilatasi terhadap pembuluh darah yang membantu melindungi fungsi jantung dan flavonoid juga dapat menurunkan kekuatan arteri. Selain itu ada juga yang naik di hari ke 3 di sebabkan karna banyak pikiran.

\section{Analisis Bivariat Pengaruh Pemberian Perasan air daun cincau hijauTerhadap Tekanan Darah pada Pende rita Hipertensi}




\title{
Jurnal Kesehatan Medika Saintika
}

\author{
Volume 10 Nomor 2 |https $\% /$ jurnal.syedzasaintika.ac.id
}

Berdasarkan hasil penelitian, didapatkan selisih rata-rata tekanan darah sebelum dan sesudah diberikan perasan air daun cincau hijau (Cyclea Barbata Miers) yaitu 5,500/8,50 mmHg. Hasil uji statistik t-test dependendan Willxocondidapatkan nilai $\mathrm{p}=0,000$ berarti pada $\alpha<0,05$ terlihat ada pengaruh pemberian perasan air daun cincau hijau terhadap penurunan tekanan darah sistolik dan diastolic pada penderita hipertensi di Wilayah Kerja Puskesmas Andalas Tahun 2018.

Hasil penelitian ini sejalan dengan penelitian yang dilakukan oleh Siti Zakiah Zulfa, (2016) tentang pengaruh pemberian perasan air daun cincau hijau terhadap tekanan darah pada penderita hipertensi di Dusun Sleman 3 Triharjo Sleman Yogyakarta, Tekanan darah systole sebelum pemberian perasan air daun cincau hijau rata-rata 154,58 $\mathrm{mmHg}$, terjadi penurunan menjadi 132,50 mmHg. Sedangkan tekanan darah diastole sebelum pemberian perasan air daun cincau hijau rata-rata 94,17 $\mathrm{mmHg}$ terjadi penurunan menjadi $81,67 \mathrm{mmHg}$. Menunjukkan bahwa ada pengaruh secara signifikan perasan air daun cincau hijau terhadap perubahan tekanan darah tinggi pada penderita hipertensi $(p=0,000)$.

Perasan air daun cincau hijau mengandung flavonoid dan alkaloid yang tinggi, kandungan zat aktif flavonoid dapat memberikan efek vasodilatasi terhadap pembuluh darah yang membantu melindungi fungsi jantung. Menurut Guyton (2008). perasan air daun cincau hijau diketahui mengandung klorofil, serta senyawa bioaktif flavonoiddapat memberikan efek vasodilatasi terhadap pembuluh darah yang membantu melindungi fungsi jantung dan flavonoid juga dapat menurunkan kekuatan arteri (Sabilla, 2016).
Peneliti berasumsi ada pengaruh pemberian perasan air daun cincau hijau terhadap penurunan tekanan darah sistolik dan diastolic pada penderitahipertensi diwilayah kerja Puskesmas Andalas Padang tahun 2018. Hal ini dikarenakan didalam perasan air daun cincau hijau diketahui mengandung klorofil, serta senyawa bioaktif flavonoiddapat memberikan efek vasodilatasi terhadap pembuluh darah yang membantu melindungi fungsi jantung dan flavonoid juga dapat menurunkan kekuatan arteri.

Terapitersebut jika tidak sesuai dengan dosis yangtepat kemungkinan besar efektifitasnya juga tidak akan terbukti, oleh karena itu konsumsi perasan air daun cincau hijau sesuai dosis $200 \mathrm{ml} 1$ kali sehari diminum pada siang hari selama 7 hari dapat menstabilkan tekanan darah.

\section{KESIMPULAN DAN SARAN Kesimpulan}

Hasil yang telah didapatkan tentang pengaruh Perasan Air Daun Cincau Hijau (Cyclea Barbata Miers)terhadap penurunan tekanan darah pada penderita hipertensi di Wilayah Kerja Puskesmas Andalas Tahun 2018, dapat ditarik kesimpulan sebagai berikut:

1. Rata-rata tekanan darah penderita hipertensi sebelum diberikan Perasan Air Daun Cincau Hijau (Cyclea Barbata Miers)yaitu 156,25/95,38 $\mathrm{mmHg}$

2. Rata-rata tekanan darah penderita hipertensi sesudah diberikan Perasan Air Daun Cincau Hijau (Cyclea Barbata Miers)yaitu 150,75/91,62 $\mathrm{mmHg}$

3. Ada pengaruh Perasan Air Daun Cincau Hijau (Cyclea Barbata Miers)terhadap penurunan tekanan darah sistolik dan diastolik pada penderita hipertensi dengan nilai $\mathrm{P}$ Value $0,000<0,05$. 


\section{Saran}

Berdasarkan kesimpulan yang didapatkan dari hasil penelitian maka peneliti menyarankan Melalui pimpinan puskesmas, agar memberikan pendidikan kesehatan tentang pemanfaatan tanaman obat tradisional khususnya pengunaan perasan air daun cincau hijau untuk masyarakat dan keluarga dalam langkah pertama pencegahan penyakit hipertensi, dengan harapan angka kejadian hipertensi mengalami penurunan setiap tahun. Kepada peneliti selanjutnya agar melakukan penelitian selanjutnya dengan menggunakan terapi non farmakologi lain dalam menurunkan hipertensi pada pasien hipertensi seperti pemberian jus wortel, daun salam, jus mentimun, rebusan daun alpukat, rebusan seledri dan lain-lain.

\section{DAFTAR PUSTAKA}

Aspiani. 2016. Buku Ajar Asuhan Keperawatan Klien Gangguan Kardiovaskular. Penerbit Buku Kedokteran EGC.

Atmawati dkk, 2014. Keragaman Daun Cincau Hijau Rambat (Cyclea Barbata Miers) Berdasarkan

Karakter Marfologi Di Kabupaten Purworejo. Mahasiswa Prodi Biosain

Pascasarjana UNS.

Brunner, L dan Suddarth, D. 2010. Buku Ajar Keperawatan Medical Bedah $(\mathrm{H}$. Kuncara,

A. Hartono, M. Ester, Y. Asih, Terjemahan). (Ed.8) Vol 2. Jakarta: EGC.

Borzecki, A. M., Kader, B., \&
Berlowitz, D. R. (2010). The epidemiology and management of severe hypertension. Journal of Human Hypertension. https://doi. org/10.1038/jhh.2009.37

Davay, P. 2005. At a Glance Medicine. Jakarta: Erlangga.

Dinas Kesehatan Provinsi Kota Padang. 2017. Data Hipertensi Puskesmas Kota Padang:

Guyton \& Hall.2006. Buku Ajar Fisiologi Kedokteran. Ed. 11. Jakarta : EGC.

Islamiah \& Sukohar. 2017. Efektivitas Kandungan Zat Aktif Daun Cincau Hijau (Cyclea Barbata Miers) Dalam Melindungi Mukosa Lambung Terhadap Ketidakseimbangan Faktor Agresif dan Faktor Defensif Lambung. Mahasiswa, Fakultas Kedokteran, Universitas Lampung.

Istiroha dkk. 2016. Efektifitas Air Perasan Daun Cincau Hijau dan Obat Hipertensi Terhadap Tingkat Hipertensi. Program Studi Ilmu Keperawatan Fakultas Ilmu Kesehatan Universitas Gresik J1. A.R. Hakim No. 2B Gresik.

Notoadmodjo, S. 2012.Metodologi Penelitian Kesehatan. Jakarta : Rineka Cipta.

Nursheha \& Febrianti. 2015. Pengaruh Ekstrak Daun Cincau Hijau( Cyclea Barbata Miers.) terhadap Gambaran Histopatologik Hepar Mencit ( Mus Musculus) yang Di induksi MSG sebagai Sumber Belajar 


\section{Jurnal Kesehatan Medika Saintika}

Volume 10 Nomor 2 | https $/ /$ jurnal.syedzasaintika.ac.id

Biologi SMA Kelas XI. Program Studi Pendidikan Biologi, FKIP, Universitas Ahmad Dahlan.

Puskesmas Andalas. 2018. Laporan Puskesmas Andalas Bulanan Tahun 2018. Kota Padang :Puskesmas Andalas.

Putra. 2017. Pengaruh Pemberian Cincau Hijau Terhadap Perubahan Tekanan Darah Penderita Hipertensi Usia 40-60 tahun di Dusun Depok Ambar ketawang Gamping Sleman Yogyakarta.

Sabilla \& Soleha. 2016. Manfaat Ekstrak Daun Cincau Hijau( Cyclea Barbata Miers.) Sebagai Alternatif Terapi Hipertensi. Mahasiswa, fakultas Kedokteran, Universitas Lampung.s

Seke dkk. 2016. Hubungan Kejadian Stres dengan Penyakit Hipertensi pada Lansia di Balai Penyantunan Lanjut Usia Senjah Cerah Kecamatan Mapanget Kota Manado. Jurnal Keperawatan Program Studi Ilmu Keperewatan Fakultas Kedokteran Universitas Sam Ratulangi Manado.

Sugiyono. 2010. Metode Penelitian Pendidikan. Bandung : Alfabeta.

Sundari dkk. (2014). Minuman Cincau Hijau Dapat Menurunkan Tekanan Darah Pada Wanita Dewasa Penderita Hipertensi Ringan Dan Sedang. Institut Pertanian Bogor.
Udjianti. 2010. Keperawatan Kardiovaskular. Jakarta : Salemba Medika.

WHO. 2013. A Global Brief On Hypertension Silent Killer, Global Public Crisis.Geneva : WHO Press. 